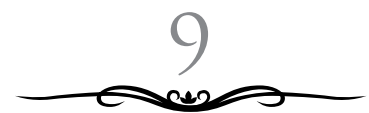

\title{
LITERASI INFORMASI MAHASISWA STAIN KUDUS DALAM MEMANFAATKAN DIGITAL LIBRARY
}

\author{
Siti Malaiha Dewi dan Rochanah \\ STAIN Kudus, Jawa Tengah, Indonesia \\ dewimalaiha@stainkudus.ac.id; Nhae08@gmail.com
}

\begin{abstract}
The rapid development of technology is responded by the world of education, especially the library by metamorphosed its service form from manual to digital. One of them is the availability of digital library with EPrints application. At STAIN Kudus, after just over a year of application, only a few students have enough information literacy in the use of EPrints as their reference resource for completing their college assignments, while most others still do not have information literacy. Those who are literate have the ability of tool literacy, resource literacy and research literacy, while the ability of publishing literacy has not yet been mastered by them. The dominant cause of the lack of the illiterate of STAIN Kudus Students is their unfamiliarity in using digital media. They are still common to use references and library services in manual. The unfamiliarity is caused by the lack of the massive socialization done by the library and lecturers in stimulating students as an independent literacy society in learning and seeking information.
\end{abstract}

Keywords: Information Literacy, Students of STAIN Kudus, Digital Library 


\begin{abstract}
Abstrak
Perkembangan teknologi yang begitu pesat direspon oleh dunia pendidikan khususnya perpustakaan dengan bermetamorfofis bentuk pelayanannya dari manual ke digital. Salah satunya yaitu tersedianya digital library dengan aplikasi EPrints. Di STAIN Kudus, Setelah berjalan lebih dari setahun aplikasi tersebut dihadirkan, ternyata hanya sebagian saja mahasiswa memiliki cukup literasi informasi dalam penggunaan EPrints sebagai sumber referensi penyelesaian tugas kuliah mereka, sementara sebagian besar lainya masih belum memiliki literasi informasi. Mereka yang sudah literat memiliki kemampuan tool literacy, resource literacy dan research literacy. Sementara kemampuan publishing literacy belum mereka miliki. Factor dominan yang menjadi penyebab belum literatnya mahasiswa STAIN Kudus adalah ketidakbiasaan mereka dalam mengggunakan media digital. Mereka masih terbiasa menggunakan referensi maupun pelayanan perpustakaan yang sifatnya manual. Ketidakbiasaan tersebut disebabkan kurang masifnya sosialisasi yang dilakukan oleh pihak perpustakaan maupun dosen dalam menciptakan mahasiswa sebagai masyarakat literasi yang mandiri dalam belajar dan mencari informasi.
\end{abstract}

Kata Kunci: Literasi Informasi, Mahasiswa STAIN Kudus, Digital Library

\title{
A. Pendahuluan
}

Seorang futuristic John Naisbit \& Patricia Aburdene dalam buku yang berjudul "Megatrends 2000: New Direction for Tomorrow" yang telah diterjemahkan oleh Penerbit Bina Rupa Aksara Jakarta di Tahun 1990 memprediksikan bahwa "dunia akan menjadi satu".

Tidak dibutuhkan waktu yang lama, apa yang diprediksi oleh John Naisbit \& Patricia Aburdene tersebut menjadi kenyataan. Letak geografis yang meski berjauhan tidak membuat antar individu, antar kelompok, bahkan antar negara tidak saling mengetahui. Trend baju, tas, alat komunikasi, lagu, bahan bacaan dan lainya di satu negara pun menjadi trend di negara lain. Satu peristiwa di daerah yang sangat pelosok di suatu negara pun bisa diketahui oleh warga di negara lainya.

Kenapa demikian? Masih menurut John Naisbit \& Patricia Aburdene, menduniannya negara-negara tersebut atau disebut 
dengan globalisasi terjadi akibat perubahan teknologi yang awalnya mengandalkan kekuatan tenaga ke teknologi canggih. Akibatnya, terjadi perubahan dari masyarakat industri ke masyarakat informative.

Ciri masyarakat informative dalam Wikipedia diantaranya ditandai dengan ketergantungan pada inovasi teknologi dan tingginya kebutuhan informasi, baik untuk berinteraksi antar manusia maupun untuk menunjang kegiatan kerja, kegiatan sosial, pengajaran, serta aktivitas lainya.

Terkait dengan bidang pendidikan, Putu Laxman Pendit menyatakan bahwa telah terjadi perubahan besar-besaran dan fundamental di dunia pendidikan khususnya pendidikan tinggi. Salah satunya pada aspek teaching and learning methods dimana terjadi kecenderungan belajar secara otonom (autonomous learning) dengan memanfaatkan berbagai teknologi informasi, baik dalam pengajaran maupun pengujian ${ }^{1}$.

Perubahan dalam komunikasi ilmiah yang mengarah ke e-learning dan e-research, maka menjadi kebutuhan yang mendesak bagi perguruan tinggi untuk menciptakan information literacy ${ }^{2}$.

Information literacy didefinisikan oleh American Library Association (ALA) Presidential Committee on Information Literacy dalam Putu Laxman Pendit sebagai berikut: '.. to be information literate, a person must be able to recognize when information is needed and have the ability to locate, evaluate, and use effectively the needed information. ${ }^{3}$ Berdasar definisi tersebut maka perpustakaan sebagai sumber referensi di perguruan tinggi sangat strategis menjadi media pemenuhan berbagai kebutuhan dosen, mahasiswa dan semua civitas akademika.

Salah satu terobosan yang dilakukan adalah perpustakaan adalah adanya layanan digital library. Digital Library Federation dalam Putu Laxman Pendit mendefinisikan digital library sebagai berikut: "Digital libraries are organizations that provide the resources,

1 Putu Laxman Pendit, "Perpustakaan Digital Perguruan Tinggi : Tantangan Peningkatan Kualitas Jasa," Cita Karyakarsa Mandiri 7 (2009): 3.

2 Ibid.

${ }^{3}$ Ibid., 7. 
including the specialized staff, to select, structure, offer intellectual access to, interpret, distribute, preserve the integrity of, and ensure the persistence over time of collections of digital works so that they are readily and economically available for use by a defined community or set of communities".

Definisi di atas terkandung konsep digital library sebagai penyediaan informasi yang bersifat memudahkan dengan memakai teknologi yang mengintegrasikan kemampuan menciptakan, mencari, dan menggunakan informasi dalam berbagai bentuk di dalam sebuah jaringan digital yang tersebar luas, memanfaatkan koleksi yang mencakup data dan metadata yang saling mengaitkan berbagai data, baik di lingkungan internal maupun eksternal, didukung oleh kegiatan mengoleksi dan mengatur sumberdaya digital yang dikembangkan bersama-sama komunitas pemakai jasa untuk memenuhi kebutuhan informasi komunitas tersebut dalam hal ini adalah civitas akademika.

Senada dengan definisi di atas, Ikhwan Arif mendefinisikan digital library sebagai penerapan teknologi informasi dalam perpustakaan. Penerapan teknologi informasi di perpustakaan dapat difungsikan dalam berbagai bentuk, antara lain: 1) Penerapan teknologi informasi digunakan sebagai Sistem Informasi Manajemen Perpustakaan. Bidang pekerjaan yang dapat diintegrasikan dengan sistem informasi perpustakaan adalah pengadaan, inventarisasi, katalogisasi, sirkulasi bahan pustaka, pengelolaan anggota, statistik dan lain sebagainya. Fungsi ini sering diistilahkan sebagai bentuk Automasi Perpustakaan; dan 2) Penerapan teknologi informasi sebagai sarana untuk menyimpan, mendapatkan dan menyebarluaskan informasi ilmu pengetahuan dalam format digital ${ }^{5}$.

Koleksi dalam digital library mengarah pada e-journal, e-book, dan sejenisnya yang terwadahi dalam aplikasi EPrints. EPrints adalah perangkat lunak opensource yang bisa digunakan untuk menyimpan berbagai makalah, hasil penelitian, gambar, bahkan video.

4 Ibid., 13.

${ }^{5}$ Ikhwan Arif, "Konsep dan Perencanaan dalam Automasi Perpustakaan," in Membangun Jaringan Perpustakaan Digital dan Otomasi Perpustaaan menuju Masyarakat Berbasis Pengetahuan, 2003, 1. 
STAIN Kudus sebagai salah satu kampus negeri di wilayah Pantura dengan sepuluh ribu lebih mahasiswa pun sudah melakukan berbagai terobosan terkait pemanfaatan teknologi diantaranya dengan membuka aplikasi EPrints. Layanan EPrints di STAIN Kudus ini mulai dihadirkan pada Tahun 2016. Eprints ini dihadirkan dengan tujuan memberikan kemudahan akses ke koleksi digital yang mencakup hasil karya dosen STAIN Kudus dan karya mahasiswa STAIN Kudus untuk masyarakat luas. Alamat yang dapat diakses pada saat mengunjungi fasilitas EPrints STAIN Kudus adalah eprints.stainkudus.ac.id. Koleksi yang disediakan dari layanan eprints ini meliputi; artikel jurnal, artikel surat kabar, skripsi, tesis, laporan penelitian, laporan PPL (Praktik Profesi Lapangan), laporan KKN (Kuliah Kerja Nyata), PKL (Praktik Kerja Lapngan), prosiding, dan informasi lain tentang STAIN Kudus.

Berdasarkan hasil wawancara dengan mahasiswa STAIN Kudus diketahui bahwa mahasiswa belum memanfaatkan digital library khususnya aplikasi EPrints dalam mendukung penyelesaian tugastugas perkuliahan maupun untuk sekedar memperkaya informasi dan wawasan. Mereka lebih suka menggunakan metode manual dengan datang langsung ke perpustakaan meskipun antrianya mengular. Hasil observasi yang peneliti lakukan pada bulan Mei 2017 menunjukkan bahwa mahasiswa mengantri hingga lima belas meter untuk sekedar mengembalikan buku pinjaman di perpustakaan STAIN Kudus.

Berdasar fakta dan realita di atas, maka tulisan ini hadir untuk mengungkap pengetahuan mahasiswa tentang aplikasi EPrints dan sejauhmana penggunaan aplikasi tersebut dalam pemenuhan tugastugas perkuliahan maupun penyusunan skripsi.

Pendekatan dalam penulisan ini adalah kualitatif dengan mengambil data utama dari mahasiswa Tarbiyah STAIN Kudus yang sedang menyusun skripsi. Mereka dianggap sebagai key person yang sering menggunakan layanan perpustakaan. Selain mahasiswa, wawancara juga dilakukan kepada Pimpinan Perpustakaan STAIN Kudus. Hasil wawancara, observasi dan dokumentasi yang terkumpul kemudian dianalisa untuk diperoleh gambaran mengenai pengetahuan mereka tentang digital library sebagai salah satu bagian pelayanan perpustakaan di STAIN Kudus. 


\section{B. Pembahasan}

\section{Sekilas tentang Literacy Informasi}

Kalarensi Naibobo mendefinisikan literasi sebagai sebuah kemampuan membaca dan menulis. ${ }^{6} \mathrm{Di}$ Indonesia orang yang memiliki kemampuan baca tulis dikenal dengan melek huruf atau aksara. Namun, saat ini literasi sudah mengalami perluasan makna. Literasi juga digunakan pada literasi komputer (computer literacy) bermakna literasi komputer, literasi media (media literacy), literasi teknologi (technology literacy), literasi ekonomi (economy literacy), literasi informasi (information literacy), bahkan ada literasi moral (moral literacy). Begitu pun orang yang literat, dimaknai sebagai orang yang sudah bisa memahami sesuatu karena membaca informasi yang tepat dan melakukan pemahamannya terhadap isi bacaan tersebut.

Literasi seseorang tidak muncul begitu saja. Tidak ada manusia yang sudah literat sejak lahir. Menciptakan generasi literat membutuhkan proses panjang dan sarana yang kondusif. Proses ini dimulai dari kecil dari lingkungan keluarga, lalu didukung atau dikembangkan di sekolah, lingkungan pergaulan, sampai lingkungan pekerjaan. ${ }^{7}$ Khusus di dunia pendidikan, pola pembelajaran di sekolah dan ketersediaan bahan bacaan di perpustakaan menjadi factor yang dominan literat tidaknya seseorang.

Seiring dengan perkembangan teknologi yang semakin pesat maka informasi melalui media digital sudah menjadi komoditas utama dalam interaksi manusia. Jaringan intrenet, hotspot, wifi sudah menjadi kebutuhan dasar manusia yang tidak bisa ditunda.

Zurkowski orang pertama yang menggunakan konsep literasi informasi sebagaimana dikutip dalam Behrens menyatakan bahwa orang yang terlatih untuk menggunakan sumber-sumber informasi dalam menyelesaikan tugas mereka disebut orang yang melek informasi (information literate). Mereka telah mempelajari teknik dan kemampuan menggunakan alat-alat dan sumber utama informasi

\footnotetext{
6 Kalarensi Naibaho, "Menciptakan Generasi Literat Melalui Perpustakaan," Perpusnas RI, 2007, 4.

7 Ibid.
} 
dalam pemecahan masalah mereka. Konsep ini didukung oleh Burchinal dengan mengatakan : "Untuk menjadi orang yang melek informasi, dibutuhkan serangkaian keahlian, antara lain bagaimana cara mencari dan menggunakan informasi yang diperlukan untuk pemecahan masalah dan pengambilan keputusan secara efektif dan efisien ${ }^{8}$.

Kuhlthau memberikan sudut pandang yang tidak jauh berbeda, yaitu bahwa literasi informasi lebih mengarah ke functional literacy, yang mencakup kemampuan membaca dan menggunakan informasi dalam kehidupan sehari-hari, termasuk mengetahui suatu informasi yang diperlukan dan menelusuri informasi untuk mengambil keputusan yang tepat ${ }^{9}$. Sedangkan Jan Olsen dan Coons dalam Behrens memandang literasi informasi dengan cakupan yang lebih luas, yakni memiliki kemampuan untuk menemukan, memanggil ulang informasi, mempergunakannya dalam pengambilan keputusan, serta memiliki kemampuan untuk menghasilkan serta memanipulasi informasi dengan menggunakan proses elektronik ${ }^{10}$.

Ada tujuh keterampilan yang dibutuhkan seseorang bisa dikatakan literat informasi di era digital menurut Hapiro dan Hughes yaitu:

1. Tool literacy, kemampuan memahami dan mengunakan alat teknologi informasi secara konseptual maupun praktikal, termasuk di dalamnya kemampuan menggunakan perangkat lunak, keras, multimedia, yang relevan dengan bidang kerja atau sutdi;

2. Resource literacy, kemampuan memahami bentuk, format, lokasi, dan cara mendapatkan sumberdaya informasi, terutama dari jaringan informasi yang terus berkembang;

3. Social-structural literacy, alias pemahaman yang benar tentang bagaimana informasi dihasilkan oleh berbagai pihak di dalam sebuah masyarakat. Ini artinya memahami siapasiapa yang berada di balik produksi informasi ilmiah, jaringan

${ }^{8}$ Ibid., 6.

${ }^{9}$ Ibid., 7.

${ }^{10}$ Ibid. 
ilmuan mana yang menghasilkannya, apa kaitannya antara satu produsen dengan produsen lainnya;

4. Research literacy, merupakan kemampuan menggunakan peralatan berbasis teknologi informasi sebagai alat riset;

5. Publishing literacy, kemampuan untuk menyusun dan menerbitkan publikasi dan ide ilmiah ke kalangan luas dengan memanfaatkan komputer dan Internet. Kemajuan teknologi saat ini, ditambah dengan gerakan-gerakan yang 'membebaskan' para ilmuan dari kukungan tradisi ilmu yang ketat di jaman cetakan, membuka kesempatan amat luas bagi setiap orang untuk menampilkan pemikirannya di Internet. Kemampuan membuat situs di Internet dan merawat serta mengundang pengunjung dalam jumlah besar, kini nyaris menjadi tuntutan umum bagi para cendekiawan;

6. Emerging technology literacy, adalah kemampuan yang memungkinkan seseorang untuk terus menerus menyesuaikan diri dengan perkembangan teknologi dan bahkan bersamasama komunitasnya ikut menentukan arah pemanfaatan teknologi informasi untuk kepentingan pengembangan ilmu;

7. Critical literacy, merupakan kemampuan melakukan evaluasi secara kritis terhadap untung-ruginya menggunakan teknologi dalam kegiatan ilmiah ${ }^{11}$.

Berbagai definisi dan prasyarat literasi informasi di atas maka bisa dikatakan bahwa literasi informasi itu sangat kompleks. Seseorang bisa dikatakan literat informasi jika mampu mencari dan menggunakan informasi yang diperlukan untuk pemecahan masalah dan pengambilan keputusan secara efektif dan efisien.

Jika dikaitkan dengan mahasiswa, maka mahasiswa dikatakan literat informasi jika mampu mencari dan menggunakan informasi yang diperlukan untuk menyelesaikan tugas perkuliahan secara efektif dan efisien. Disinilah Perpustakaan memiliki kontribusi besar untuk membentuk mahasiswa literat yaitu mahasiswa yang bukan hanya mempunyai banyak informasi, tetapi mahasiswa yang mengetahui

11 Putu Laxman Pendit, "Perpustakaan Digital: Kesinambungan dan Dinamika," Jurnal Pustakawan Indonesia 10, no. 1 (n.d.): 8-9. 
bagaimana mencari, mengevaluasi dan menggunakan informasi yang dibutuhkannya dalam mendukung proses belajarnya ${ }^{12}$.

Senada dengan definisi di atas, UNESCO mendefinisikan seseorang dikatakan literat jika: "Information literate people have been described as those who know when they need information, and are then able to identify, locate, evaluate, organise, and effectively use the information to address and help resolve personal, job releted, or broader social issues and problems", seseorang yang beraksara informasi adalah orang yang mengetahui bila mana mereka membutuhkan informasi, kemudian mampu meng identifikasi, menemukan, mengevaluasi, mengorganisasi, dan menggunakan informasi itu secara efektif untuk menjawab dan membantu menyelesaikan masalah/isu personal, pekerjaan, dan masalah sosial yang lebih luas ${ }^{13}$.

\section{Literasi Informasi Mahasiswa STAIN Kudus}

Literasi informasi yang dimaksud dalam tulisan ini adalah sejauhmana pengetahuan, kemampuan mencari dan menggunakan digital library dalam hal ini aplikasi EPrints sebagai sumber informasi dalam menyelesaikan tugas perkuliahan mereka.

Sebagaimana disebutkan pada bab pendahuluan, layanan EPrints di STAIN Kudus mulai dibangun pada Tahun 2016. Eprints dihadirkan dengan tujuan memberikan kemudahan akses ke koleksi digital yang mencakup hasil karya dosen STAIN Kudus dan karya mahasiswa STAIN Kudus. Alamat yang dapat diakses pada saat mengunjungi EPrints STAIN Kudus adalah eprints.stainkudus. ac.id. Koleksi yang disediakan layanan eprints ini meliputi; artikel jurnal, artikel surat kabar, skripsi, tesis, laporan penelitian, laporan PPL (Praktik Profesi Lapangan), laporan KKN (Kuliah Kerja Nyata), PKL (Praktik Kerja Lapngan), prosiding, dan informasi lain tentang STAIN Kudus.

12 Sitti Husaebah Pattah, "Literasi Informasi: Peningkatan Kompetensi Informasi dalam Proses Pembelajaran," Jurnal Ilmu Perpustakaan \& Kearsipan Khizanah Al- Hikmah 2, no. 2 (2014): 9.

13 Ummi Rodliyah, "Literasi Informasi dan Peran Perpustakaan dalam Meningkatkan SDM," Pustakaloka 4, no. 1 (2012): 3. 
Berdasar hasil wawancara diketahui bahwa Mayoritas mahasiswa STAIN Kudus belum mengetahui adanya EPrints di STAIN Kudus, bahkan ada yang menyatakan baru pertama mendengar istilah EPrints saat diwawancara. Hanya sebagian kecil yang tahu tentang aplikasi EPrints karena pernah iseng buka-buka website STAIN Kudus. Ada juga yang tahu dari teman lainya bahwa salah satu syarat wisuda harus menyerahkan file skripsi untuk diunggah di website STAIN oleh petugas perpustakaan, dan ada juga yang membaca pengumuman yang ditempel di berbagai lokasi strategis di kampus untuk bisa menggunakan EPrints sebagai referensi penyusunan skripsi.

Mereka yang tidak mengetahui tentang EPrints menyatakan bahwa mereka malas membuka website STAIN Kudus. Kalaupun mencari referensi lebih suka secara manual. "lebih nyaman membaca buku cetak”, ungkap mereka. Hal yang sama juga diucapkan oleh mereka yang sudah mengetahui aplikasi EPrints. Mereka lebih suka mengantri meskipun lama, sebab mereka merasa lebih nyaman dengan membaca buku maupun skripsinya langsung. Bahkan ada yang sudah mencari sumber referensi dari EPrints setelah mendapatkan filenya dicetak juga.

Penyebab mereka enggan menggunakan media digital adalah karena factor ketidakbiasaan. Bukan factor ekonomi ataupun yang lain. Merubah pola membaca dari cetak ke digital dibutuhkan waktu yang lama sebab pembiasaan hanya bisa diciptakan melalui proses yang terus menerus. Maka, sosialisasi tidak hanya dilakukan seperti biasanya yaitu ketika mereka masuk menjadi mahasiswa dalam program orientasi mahasiswa baru, tetapi secara massif harus dilakukan oleh dosen selama pembelajaran dengan menekankan pada model pebelajaran yang mandiri dengan menggunakan referensi digital.

Terkait hubungan antara kebiasaan dengan keberaksaraan informasi, sebuah penelitian pernah dilakukan oleh Depdiknas bersama Perpusnas RI tahun 1997, yang menghasilkan catatan bahwa salah satu sebab rendahnya minat baca adalah dominannya budaya tutur. Muara paling kelihatan dari efek negatif budaya tutur adalah lebih tertariknya menjadi seorang pendengar ketimbang seorang pembaca. Lebih memilih menjadi penikmat karya pengetahuan 
ketimbang menciptakan pengetahuan baru. Padahal, mendengar memiliki keterbatasan sumber, media serta kemampuan individunya. Dengan demikian budaya tutur melemahkan kepekaan seseorang akan kebutuhan informasi. ${ }^{14}$

Sebagian mahasiswa yang sudah mengetahui dan menggunakan EPrints menyatakan bahwa EPrints sangat membantu mereka dalam menyusun makalah dan skripsi sebab mereka tidak perlu capekcapek mengantri. Mereka bisa membuka dimanapun dan kapanpun tanpa harus pusing-pusing mencari sebagaimana ketika mereka lakukan secara langsung di perpustakaan. Mereka juga mengatakan bahwa yang ada di EPrints sudah sangat lengkap, baik karya dosen maupun mahasiswa ada semua. Namun, jurnal dan skripsi menjadi favorit rujukan mereka dalam menulis. Cara mengoperasikanya pun mudah, tidak ada kesulitan yang dirasakan. Mahasiswa yang demikian bisa dikategorikan sudah literat, ditandai dengan kemampuan mereka dalam menggunakan EPrints atau disebut dengan tool literacy, kemampuan menggunakan EPrints sebagai bahan penyusunan makalah atau skripsi, disebut research literacy, dan resource literacy atau kemampuan mahasiswa mengikuti perkembangan sumber informasi yang begitu pesat.

Hanya saja, kemampuan publishing literacy mahasiswa masih jauh tertinggal. Setelah menyelesaikan tugas dengan menggunakan EPrints sebagai referensi, mereka jarang mengunggah kembali ke jaringan online kecuali mendapatkan instruksi dari dosen untuk diunggah di blog maupun sejenisnya. Ada rasa tidak percaya diri dengan hasil karya mereka. Realita ini menunjukkan bahwa publishing literacy mahasiswa STAIN Kudus masih kurang.

Berdasar fakta di atas, maka pengelola perpustakaan harus mampu secara revolusioner melakukan penyesuain aspek-aspek penyelenggaraan perpustakaan yang mengacu pada perkembangan terbaru yang berbasis digital. Salmubi memetakan perubahan pustakawan yang semula hanya sebagai Collection Builder Classifier, Cataloger, Indexer Information, Retrieval Specialist Reference, Librarian

14 Aris Nurohman, "Signifikansi Literasi Informasi (Information Literacy) dalam Dunia Pendidikan di Era Global,” Jurnal Kependidikan II, no. 1 (2014): 10. 
Information, Provider Information Manager, di era digital berubah menjadi Knowledge Prospector (Pencari/Pendulang), Metadata Developers and Publisher, Knowledge Navigators and Expedition Guides Information, Analysis/Knowledge Interpreter Information Access dan Provider Knowledge Manager ${ }^{15}$. Peran-peran tersebut menunjukkan pentingnya posisi pustakawan dalam membantu menciptakan masyarakat kampus yang literat.

\section{Simpulan}

Berdasar pemaparan data di atas, maka dapat disimpulkan bahwa sebagian mahasiswa cukup memiliki literasi informasi dalam penggunaan aplikasi EPrints sebagai sumber referensi penyelesaian tugas kuliah, sementara sebagian besar masih belum disebut sebagai mahasiswa yang literat.

Beberapa factor yang menjadi penyebab belum literatnya mahasiswa adalah factor ketidakbiasaan mereka dalam mengggunakan media digital. Mereka masih terbiasa menggunakan referensi maupun pelayanan perpustakaan yang sifatnya manual. Ketidakbiasaan tersebut diantaranya disebabkan kurang masifnya sosialisasi yang dilakukan oleh pihak perpustakaan maupun dosen dalam menciptakan mahasiswa sebagai masyarakat literasi yang mandiri dalam belajar dan mencari informasi. Maka, sosialisasi semua pihak, baik dosen maupun perpustakaan perlu bersinergi dalam mewujudkan masyarakat akademik yang memiliki literasi informasi yang tinggi.

15 Salmubi, "Lanskap Baru Perpustakaan dan Pustakawan pada Era Digital," Jupiter XV, no. 1 (2016): 8. 


\section{DAFTAR PUSTAKA}

Arif, Ikhwan. "Konsep dan Perencanaan dalam Automasi Perpustakaan." In Membangun Jaringan Perpustakaan Digital dan Otomasi Perpustaaan menuju Masyarakat Berbasis Pengetahuan, 1-8, 2003.

Naibaho, Kalarensi. "Menciptakan Generasi Literat Melalui Perpustakaan." Perpusnas RI, 2007, 1-15.

Nurohman, Aris. "Signifikansi Literasi Informasi (Information Literacy) dalam Dunia Pendidikan di Era Global." Jurnal Kependidikan II, no. 1 (2014): 1-25.

Pattah, Sitti Husaebah. "Literasi Informasi: Peningkatan Kompetensi Informasi dalam Proses Pembelajaran.” Jurnal Ilmu Perpustakaan \& Kearsipan Khizanah Al- Hikmah 2, no. 2 (2014): 117-28.

Pendit, Putu Laxman. "Perpustakaan Digital: Kesinambungan dan Dinamika." Jurnal Pustakawan Indonesia 10, no. 1 (n.d.).

- - . "Perpustakaan Digital Perguruan Tinggi: Tantangan Peningkatan Kualitas Jasa." Cita Karyakarsa Mandiri 7 (2009).

Rodliyah, Ummi. "Literasi Informasi dan Peran Perpustakaan dalam Meningkatkan SDM.” Pustakaloka 4, no. 1 (2012): 48-60.

Salmubi. "Lanskap Baru Perpustakaan dan Pustakawan pada Era Digital.” Jupiter XV, no. 1 (2016): 1-9. 
